\title{
Germinative metabolism of Caatinga forest species in biosaline agriculture ${ }^{1}$
}

\author{
Bárbara França Dantas²*, Renata Conduru Ribeiro², Janete Rodrigues Matias², \\ Gherman Garcia Leal Araújo ${ }^{2}$
}

\begin{abstract}
The production of seeds and seedlings by these species is of utmost importance to prevent a loss of biodiversity of the Caatinga, a unique and exclusively Brazilian biome. Biosaline agriculture is conducted over a range of salinity levels in groundwater and/or in soils. The current study evaluated the application of biosaline agriculture to Anadenanthera macrocarpa, Myracrodruon urundeuva, Aspidosperma pyrifolium and Erythrina velutina by examining the germinative metabolism of seeds subjected to different electrical conductivities (ECs) of $\mathrm{NaCl}$ solutions and biosaline water. The seeds were germinated in biosaline

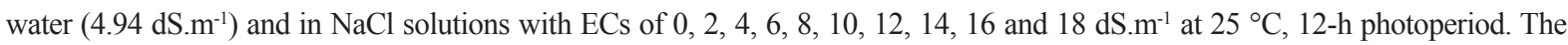
kinetic variables of germination were assessed, and the seeds and seedlings were assayed for reserve biomolecules, proline content and antioxidant enzyme activity. The seeds were highly tolerant to salinity, with germination-limiting ECs above $12 \mathrm{dS} . \mathrm{m}^{-1}$. Although high EC promoted alterations in seed metabolism that enabled salinity tolerance, seedling production was indicated with ECs no higher than $6 \mathrm{dS} \cdot \mathrm{m}^{-1}$. These results demonstrated that Caatinga seedling production is viable through biosaline agriculture beucause the groundwater salinity of this region is within the tolerance levels of the seeds.
\end{abstract}

Index terms: antioxidant enzymes, germination, reserve mobilization, salt stress.

\section{Metabolismo germinativo de espécies florestais da Caatinga em agricultura biossalina}

\begin{abstract}
RESUMO- A produção de sementes e mudas é de extrema importância para evitar a perda da biodiversidade da Caatinga, único bioma exclusivamente brasileiro. Agricultura biossalina é a produção agrícola sob uma variedade de níveis de salinidade nas águas subterrâneas e /ou em solos. Este trabalho objetivou avaliar a produção de mudas de Anadenanthera macrocarpa, Myracrodruon urundeuva, Aspidosperma pyrifolium e Erythrina velutina com agricultura biossalina, através do estudo do metabolismo germinativo das sementes submetidas a diferentes condutividades elétricas (CE) de solução salina ou água biossalina. Sementes germinaram em água biossalina $\left(4,94 \mathrm{dS} . \mathrm{m}^{-1}\right)$ e em soluções de $\mathrm{NaCl}$ com $\mathrm{CE}$ de $0,2,4,6,8,10,12,14,16,18 \mathrm{dS} \cdot \mathrm{m}^{-1}$, a $25^{\circ} \mathrm{C}$, fotoperíodo de $12 \mathrm{~h}$. Variáveis cinéticas de germinação foram avaliadas. Sementes e plântulas foram analisadas para biomoléculas de reserva, prolina e enzimas antioxidantes. As sementes da Caatinga são altamente tolerantes à salinidade, com germinação limitada em CE acima de $12 \mathrm{dS} \cdot \mathrm{m}^{-1}$. Embora, alta CE promova alterações no metabolismo sementes, permitindo tolerância à salinidade, a produção de mudas é indicada em CE inferior a $6 \mathrm{dS} \cdot \mathrm{m}^{-1}$. Assim, a produção de mudas da Caatinga é viável através da agricultura biossalina, pois as águas subterrâneas da região apresentam-se dentro deste nível.
\end{abstract}

Termos de indexação: enzimas antioxidantes, germinação, mobilização de reserva, estresse salino.

\section{Introduction}

Caatinga, the most important type of vegetation in semiarid northeastern Brazil, is reduced to less than $50 \%$ of its original area. For several decades, this vegetation has been undergoing strong anthropic pressure, mainly because of extractive activities. This type of tropical dry forest can be considered relic vegetation, presenting distinct floristic, physiognomic and ecological characteristics (Rodal et al., 2008).

Certain species native to the Caatinga can be used for a variety of purposes, such as urban landscaping (Dantas and Souza, 2004), the recovery of riparian vegetation (RibeiroFilho et al., 2009) and pharmaceutical and medicinal applications (Agra et al., 2007). These species include

\footnotetext{
${ }^{1}$ Submitted on 04/11/2013. Accepted for publication on 05/14/2014.

${ }^{2}$ Embrapa Semiárido, BR 428, Km 152, Zona Rural, Caixa Postal 23, 56302-970 - Petrolina, PE, Brasil.

*Corresponding author <barbara.dantas@embrapa.br>
} 
Anadenanthera macrocarpa (Benth.) Brenan, Myracrodruon urundeuva (Fr. All.), Aspidosperma pyrifolium (Mart.) and Erythrina velutina (Willd.). According to the Brazilian Institute of Environment and Renewable Natural Resources (IBAMA), M. urundeuva is endangered in both the Caatinga and the Cerrado (Brasil, 2008).

In arid or semiarid regions, such as areas in the Brazilian Northeast, evapotranspiration is extreme, and the plants suffer from drought. Thus, irrigation becomes the preferred practice to ensure production in the region. Despite low water availability, considerable water wastage occurs because of both the absence of effective management and the lack of commitment at all levels to activities that promote water conservation. Due to its geology, brackish groundwater reserves are common in the Brazilian semiarid region (Hirata et al., 2006). Many countries located in arid and semiarid areas have included water reuse in their water resources planning because the scarcity of good quality water has limited the development of urban, industrial and agricultural activities. In this sense, effluents are forming an integral part of the national water resources in several countries (Qadir et al., 2003).

Biosaline agriculture is a broad term used to describe agriculture under a range of salinity levels in groundwater and in wastewater and soils or a combination of both (Masters et al., 2007), such as the use of saline groundwater irrigation with nonsaline soils or with sodic soils of the type that occurs in areas with Caatinga vegetation.

Knowledge regarding the germination behavior of seeds from these native forest species is of utmost importance for the restoration of degraded lands (Araújo -Neto et al., 2003), the protection of these species from extinction (Carvalho and Nakagawa, 2012), the recomposition of the landscape and the conservation of regional biodiversity (Cabral et al., 2003). Thus, to assess the potential for the efficient production of Caatinga tree seedlings with biosaline agriculture, this study evaluated the germination and the germinative metabolism of Caatinga tree seeds subjected to high electrical conductivities (ECs) because of the use of salted and/or biosaline water.

\section{Material and Methods}

For this work, we used the seeds of the four native species of Caatinga biome mentioned above: A. macrocarpa, $M$. urundeuva, A. pyrifolium and E. velutina. The fruits of the four species were harvested between September and November 2012 from 10 mother plants located in Jutaí, Lagoa Grande, PE ( $8^{\circ} 38^{\prime} 45.23$ 'S, 40 ${ }^{\circ} 14^{\prime} 07.32$ 'W) and Juremal, Juazeiro, BA ( $9^{\circ} 43^{\prime} 51.12$ 'S, $40^{\circ} 21^{\prime} 02.52$ ' $\left.\mathrm{W}\right)$. The seeds were sun dried, processed and stored in a dry chamber at $10^{\circ} \mathrm{C}$. Before undergoing the germination tests and biochemical assays, the water content of the seeds was determined after $24 \mathrm{~h}$ at $105 \pm$ $3{ }^{\circ} \mathrm{C}$ (Brasil, 2009), using two samples of 25 seeds for each species. The results were expressed as the mean percentage for each sample.

To overcome the seed coat dormancy of the E. velutina seeds, it was necessary to scarify the seeds on the side opposite the hilum before soaking them. The seeds of the remaining species were germinated without any pretreatment. Prior to the germination tests, the seeds were surface-sterilized using sodium hypochlorite $(2 \%)$ for 2 minutes and then rinsed in distilled water.

Salt stress screening: The seeds were subjected to a salt stress screening using different $\mathrm{NaCl}$ solutions with ECs of 0 , 2, 4, 6, 8, 10, 12, 14, 16 and $18 \mathrm{dS} \cdot \mathrm{m}^{-1}$ (Richards, 1980).For germination, the seeds were placed on germitest paper rolls, which were moistened using a volume of $\mathrm{NaCl}$ solution that was 2.5 times the weight of the substrate (Brasil, 2009).

Germination in biosaline water: The seeds of all four species were germinated on a substrate of germitest paper rolls soaked, using a volume equivalent to 2.5 times the mass of the dry substrate, with distilled water (control) and with biosaline water $(33,50,67$ and $100 \%$ strengths diluted in distilled water). The biosaline water was collected from fish tanks supplied with brackish groundwater and used for raising Thai tilapia (Oreochromis sp.). The physicalchemical properties of the experimental waters are shown in Table 1.

Table 1.Analysis of the biosaline water used for substrate moistening in germination tests.

\begin{tabular}{|c|c|c|c|c|c|c|c|c|c|c|c|}
\hline \multicolumn{5}{|c|}{ Cations } & \multicolumn{5}{|c|}{ Anions } & \multirow[t]{3}{*}{$\mathrm{pH}$} & \multirow{3}{*}{$\begin{array}{c}\text { EC } \\
\text { dS.m }{ }^{-1}\end{array}$} \\
\hline $\mathrm{Ca}^{2+}$ & $\mathrm{Mg}^{2+}$ & $\mathrm{Na}^{+}$ & $\mathrm{K}^{+}$ & $\mathrm{S}^{+}$ & $\mathrm{CO}_{3}{ }^{2-}$ & $\mathrm{HCO}_{3}^{-}$ & $\mathrm{SO}_{4}{ }^{2-}$ & $\mathrm{Cl}^{-}$ & $\mathrm{S}^{-}$ & & \\
\hline \multicolumn{10}{|c|}{$\mathrm{mmol}_{\mathrm{c}} / \mathrm{L}$} & & \\
\hline
\end{tabular}

Provided by Laboratory of Soil, Water and Plants -Embrapa Tropical Semi-Arid

In both assays, the germitest paper rolls were kept in biochemical oxygen demand (BOD) germinators at a constant temperature of $25^{\circ} \mathrm{C}$ under a $12 \mathrm{~h}$ photoperiod for 15 days.
The seeds were transferred at every 3 days to fresh rolls containing the same treatments so that they were exposed to constant EC levels. 
A completely randomized experimental design was used for both assays, which included salt stress screening of ten EC treatments $\left(0,2,4,6,8,10,12,14,16\right.$ and $\left.18 \mathrm{dS} . \mathrm{m}^{-1}\right)$ and four biosaline water strengths $(0,33,50,67$ and $100 \%$ strengths diluted in distilled water), and four replications of 25 seeds for each replication.

Only seeds presenting a 2-mm long protrusion of the radicle were considered germinated and were counted daily. The variables assessed were the germination percentage, germination mean time (GMT), germination speed index (GSI) and germination uniformity coefficient (GUC) (Ranal and Santana, 2006). After these assessments, the shoots and the roots of the germinated seeds were frozen until the biochemical assays were conducted.

\section{Germinative metabolism assays}

Extraction and analysis of seed reserves: For the macromolecule extraction, $0.5 \mathrm{~g}$ of plant material was homogenized in $5 \mathrm{~mL}$ of $0.1 \mathrm{M}$ potassium phosphate buffer at $\mathrm{pH} 7.5$. After centrifugation at $10,000 \mathrm{xg}$ for 20 minutes at $4{ }^{\circ} \mathrm{C}$, the quantity of soluble metabolites in the supernatant was determined spectrophotometrically. The crude extract was used to quantify the total soluble sugars (TSSs), reducing sugars(RSs) and total soluble proteins (TSPs) (Ribeiro et al., 2012).

Proline extraction and content assay: For A. macrocarpa, A. pyrifolium and E. velutina, the quantification of proline in the shoots was based on the methodology described by Bates (1973). The assays were carried out in triplicate, and the results were expressed as the micromoles of proline per gram of fresh weight $\left(\mu \mathrm{mol} . \mathrm{g}^{-1}\right)$. The seedlings of $M$. urundeuva were not assayed for proline content.

Extraction and assay of antioxidant enzymes: For the determination of antioxidant enzymes, material was collected five days after sowing for the subsequent extraction and quantification of the activities of ascorbate peroxidase (APX, EC 1.11.1.11), catalase (CAT, EC 1.11.1.6) and glutathione-S-transferase (GST, EC 2.5.1.18) according to Ribeiro et al. (2012). All the assays were performed in triplicate.

Statistical analysis: The data on germination (G\%, GMT, GSI and GUC), seed reserves content (RSs, TSSs, TSPs) and antioxidant enzymes activities were analyzed by ANOVA and to $\mathrm{F}$ test, at $5 \%$ probability, using the statistical program Assistat (Silva and Azevedo, 2002). For ANOVA, the data on the percentage of germination were transformed by the function $(x+0$.$) 0.5. The standard error of mean was also$ determined and is presented in the graphs.

\section{Results and Discussion}

The A. macrocarpa seeds, which had an average water content of $12.85 \%$, showed no germination response to the $\mathrm{NaCl}$ solutions with ECs increasing up to $12 \mathrm{dS} . \mathrm{m}^{-1}$. With further EC increases, the germination of the seeds decreased to $78 \%$ at 18 dS.m ${ }^{-1}$, a $16 \%$ inhibition compared with $93 \%$ germination in the distilled water (Figure 1a). Above $12 \mathrm{dS} . \mathrm{m}^{-1}$ over the same EC range, the GMT (Figure 1b) and GSI (Figure 1c) were more strongly affected. For A. macrocarpa 4 day seedlings, the TSPs and RSs in the shoots increased with the EC increases (Figures 2a, b), whereas the TSSs content remained stable (Figure 2c), and the proline content decreased at the ECs higher than $4 \mathrm{dS} \cdot \mathrm{m}^{-1}$ (Figure 2d). In the roots, the TPs, RSs and TSSs contents increased at $16 \mathrm{dS} \cdot \mathrm{m}^{-1}$ (Figures 2a-c). Consistent with the results in Figure 1, the germination percentage, GMT, GSI and GUC (Figures 3a-d) were not affected by 50 or $100 \%$ biosaline water, which has an EC of approximately $5 \mathrm{dS} \cdot \mathrm{m}^{-1}$ at full strength.
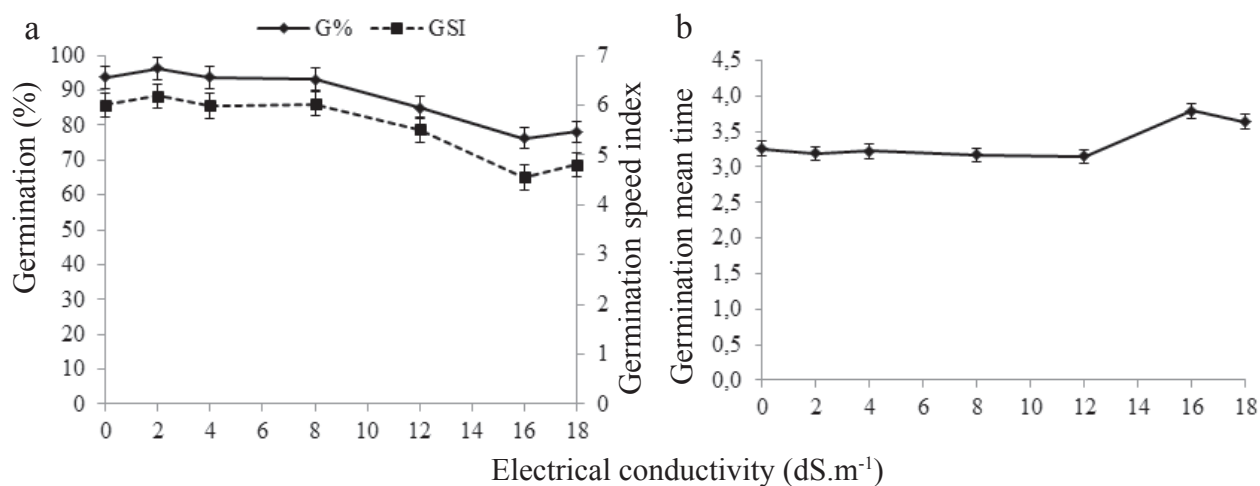

Figure 1. Germination percentage-G\%, germination speed index-GSI (a) and germination mean time-GMT (b) of A. macrocarpa seeds in different electrical conductivities. Vertical bars indicate standard errors of means. 

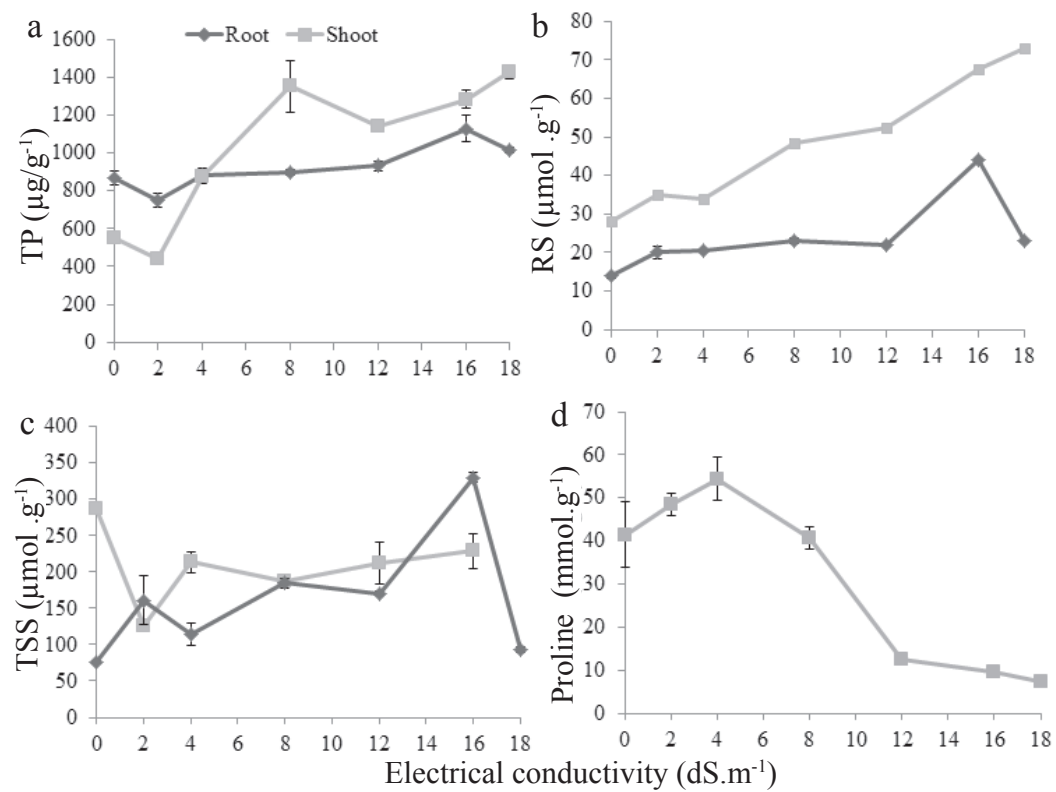

Figure 2. Total soluble proteins (a), reducing sugars (b), total soluble sugars (c) and proline (d) content in 4 days germinated $A$. macrocarpa seedlings in different electrical conductivities. Vertical bars indicate standard errors of means.

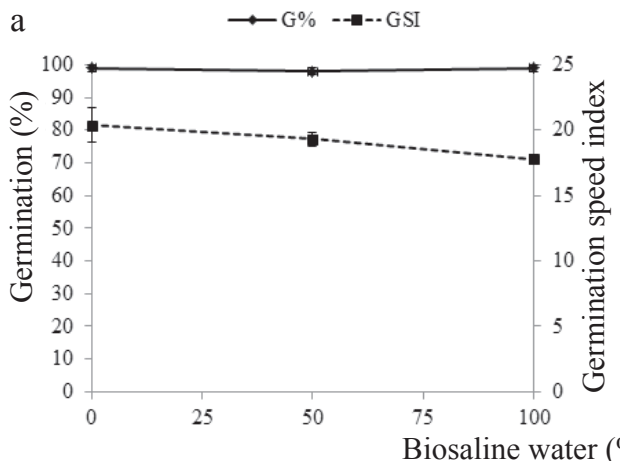

b

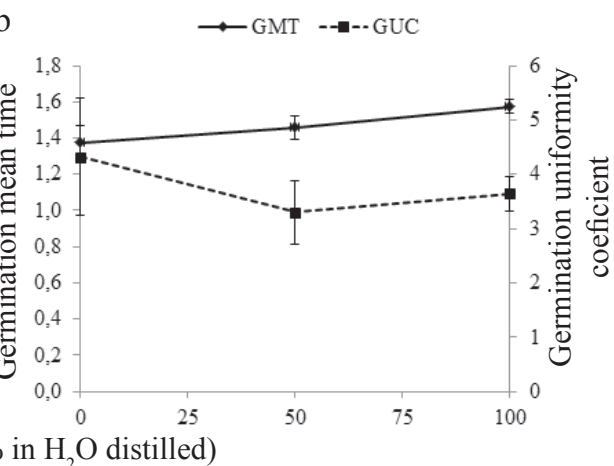

Figure 3. Germination percentage - G\%, germination speed index - GSI (a), germination mean time - GMT and germination uniformity coefficient- GUC (b) of A. macrocarpa seeds in biosaline water. Vertical bars indicate standard errors of means.

The A. pyrifolium seeds had an average water content of 9.3\%. Their germination (Figure 4a) was not affected by the EC treatments below $10 \mathrm{dS} \cdot \mathrm{m}^{-1}$; however, at this EC value and above, the GMT increased (Figure $4 \mathrm{~b}$ ) and the GSI and GUC decreased (Figures 4c, d). Similar results were observed for the A. pyrifolium seeds germinated in the biosaline water. Although germination was unaffected in the pure biosaline water (Figure 5a), the GMT, GSI and GUC (Figures 5b-d) were similarly altered by the $\mathrm{NaCl}$ solutions with ECs at and above $8 \mathrm{dS} \cdot \mathrm{m}^{-1}$ (Figures 4b-d). In 4-day A. pyrifolium seedlings, the biosaline water altered the mobilization of seed reserves (Figure 6). The leaves and roots of the seedlings presented an increased TSP content in all biosaline water treatments (Figure 6a) and an increased proline content following exposure to the $\mathrm{NaCl}$ solutions during germination (Figure 6d). However, their RSs levels initially decreased and then increased following the treatment with $67 \%$ biosaline water during germination (Figure $6 b)$. The TSSs content gradually declined in the roots but plateaued in the seedling shoots (Figure 6c).

The E. velutina seeds had an average initial moisture content of 7.4\%. As shown in Figure 7, the increase in EC had no significant effect on the seed germination parameters of $E$. velutina. Neither the germination percentage nor the GSI declined with the increasing ECs (Figures 7a, c). Without $\mathrm{NaCl}$ (control) the germination of the seeds was $100 \%$ and required 4.67 days for completion (Figure $7 \mathrm{~b}$ ). The seeds germinated in EC of $18 \mathrm{dS} . \mathrm{m}^{-1}$ required 5.96 days to reach a final germination rate of $97.8 \%$; these values did not differ from those of the control. The TSPs content in the embryonic axis of the E. velutina seeds was influenced by the increased 
EC during germination (Figure 8a). The RSs and TSSs in the axis decreased with increasing EC during germination
(Figures $8 \mathrm{~b}, \mathrm{c}$ ), but the proline content was not significantly affected (Figure 8d).

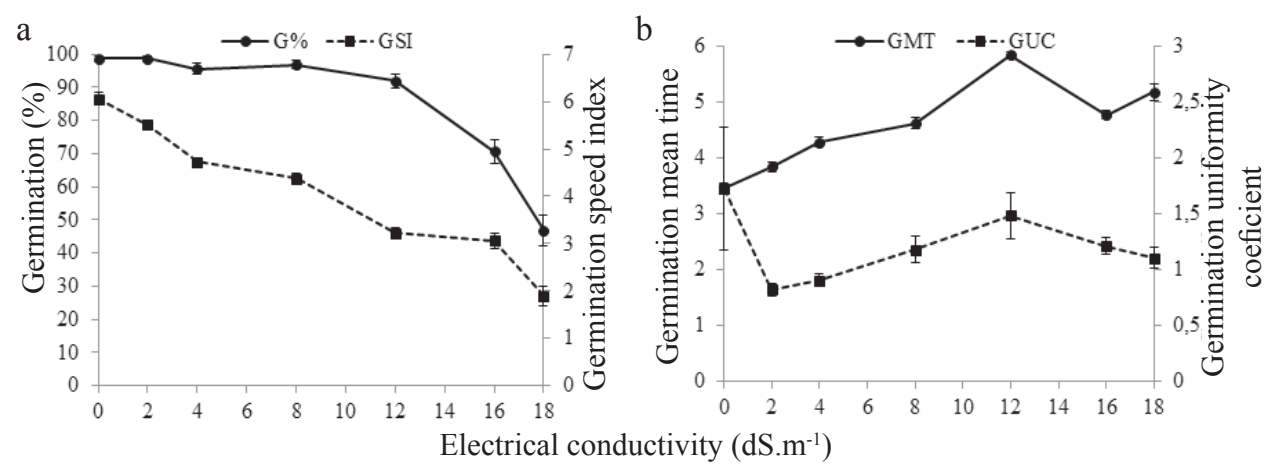

Figure 4. Germination percentage - G\%, germination speed index - GSI (a), germination mean time - GMT and germination uniformity coefficient- GUC (b) of A. pyrifolium seeds in different electrical conductivities. Vertical bars indicate standard errors of means.
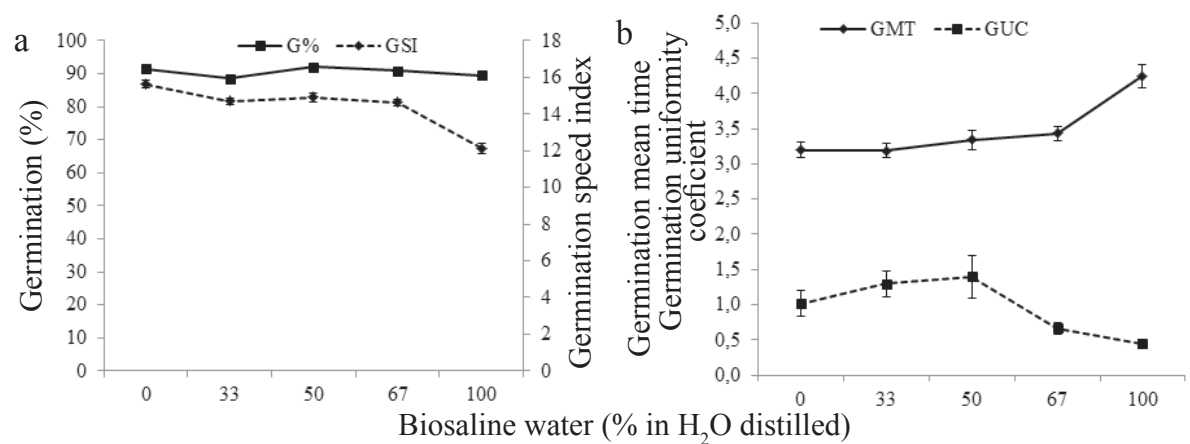

Figure 5. Germination percentage - G\%, germination speed index - GSI (a), germination mean time - GMT and germination uniformity coefficient - GUC (b) of A. pyrifolium seeds in biosaline water. Vertical bars indicate standard errors of means.
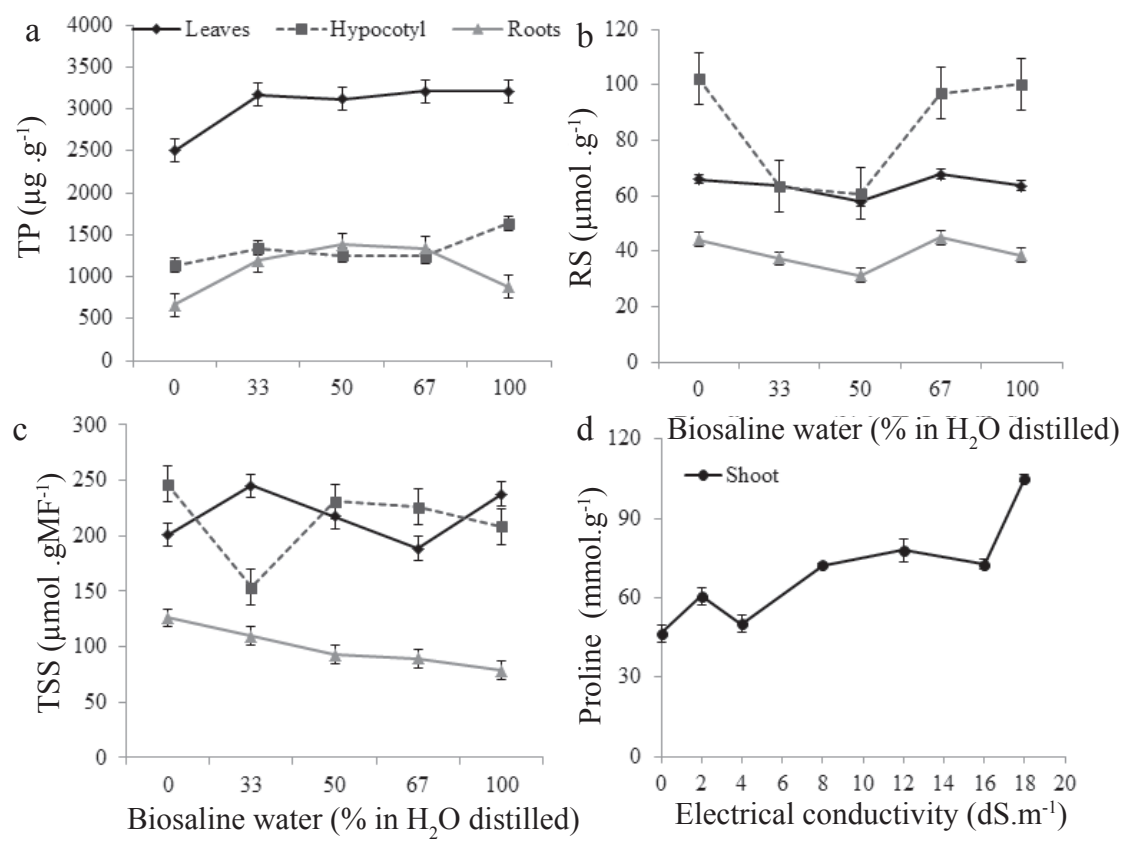

Figure 6. Total soluble proteins (a), reducing sugars (b), total soluble sugars (c) and proline (d) in 4days germinated A. pyrifolium seedlings in biosaline water (a-c) and in different electrical conductivities (d). Vertical bars indicate standard errors of means. 


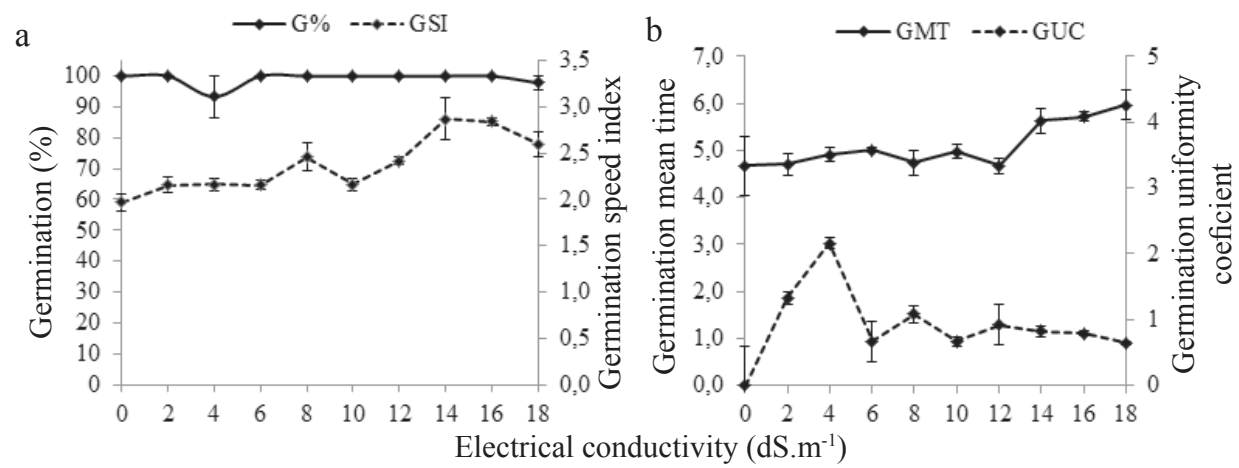

Figure 7. Germination percentage - G\%, germination speed index-GSI (a), germination mean time-GMT and germination uniformity coefficient- GUC (b) of E. velutina seeds in different electrical conductivities. Vertical bars indicate standard errors of means.
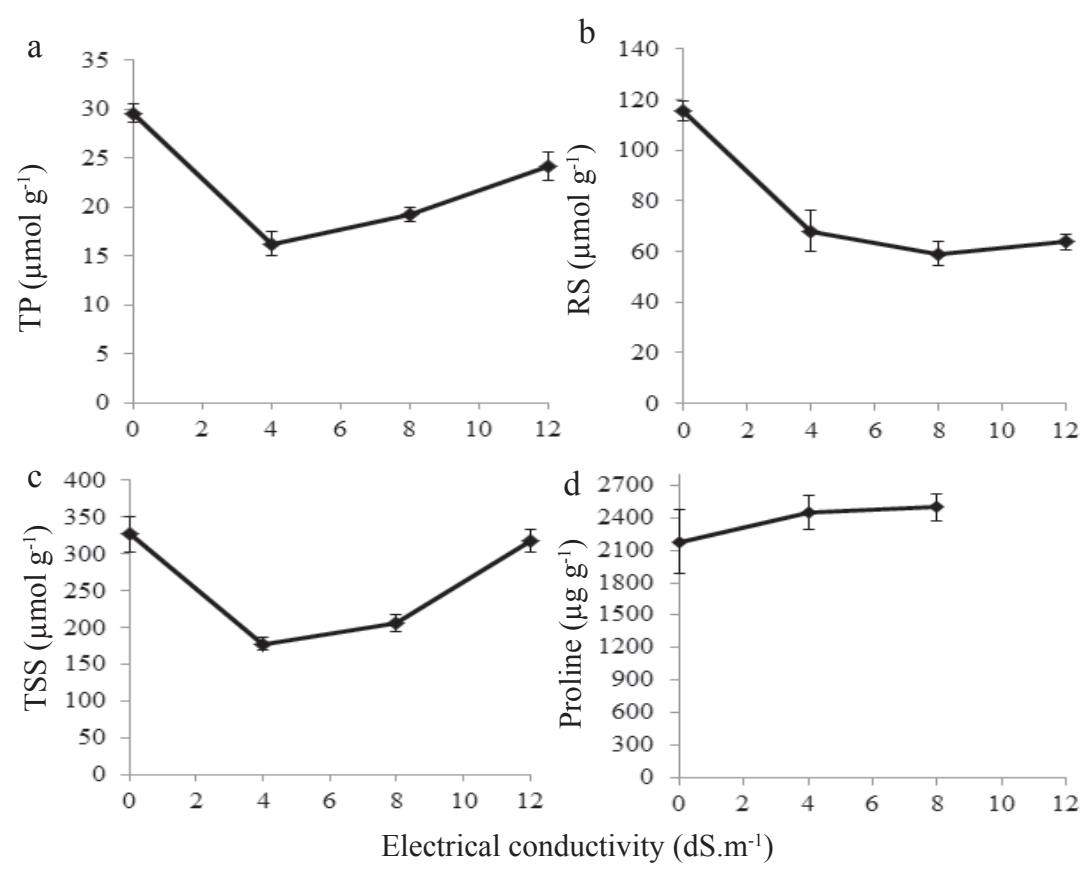

Figure 8. Total soluble proteins (a), reducing sugars (b), total soluble sugars (c) and proline (d) content in 7 days germinated $E$. velutina embryonic axis in different electrical conductivities. Vertical bars indicate standard errors of means.

With the exception of catalase (Figure 9b), the antioxidant enzymes exhibited little or no activity in the cotyledons of germinating seedlings (Figures 9a, c, d). The E. velutina seedlings showed an initial increase in antioxidant activities at $4 \mathrm{dS} \cdot \mathrm{m}^{-1}$ and a later decrease at $8 \mathrm{dS} \cdot \mathrm{m}^{-1}$ (Figure 9).

Although the biosaline water had no effect on the percentage of E. velutina seeds that germinated (Figure 10a), the half-strength biosaline solution (50\%) decreased the GMT (Figure 10b) and increased the GSI (Figure 10c). This increase in germination velocity might have resulted from better seed membrane repair caused by slower and/ or more homogeneous rehydration in the low-EC biosaline solution than in distilled water (Weitbrecht et al., 2011).
The GUC increased in the more concentrated biosaline solutions (Figure 10d).

The $M$. urundeuva seeds had an average initial moisture content of $9.46 \%$. The undiluted biosaline water did not affect the germination of the seeds harvested in 2012 (Figure 11a). However, the GMT (Figure 11b) as well as the GSI and GUC (Figures 11c, d) increased with the increasing concentrations of the biosaline solutions. The TSPs content in the leaves of the M. urundeuva seedlings was higher than in the hypocotyl-root axes and was influenced by the increases in the concentration of the biosaline solutions (Figure 12a). The RSs and TSSs in the axis also increased with increasing salinity of the biosaline solutions (Figures 12b, c). 


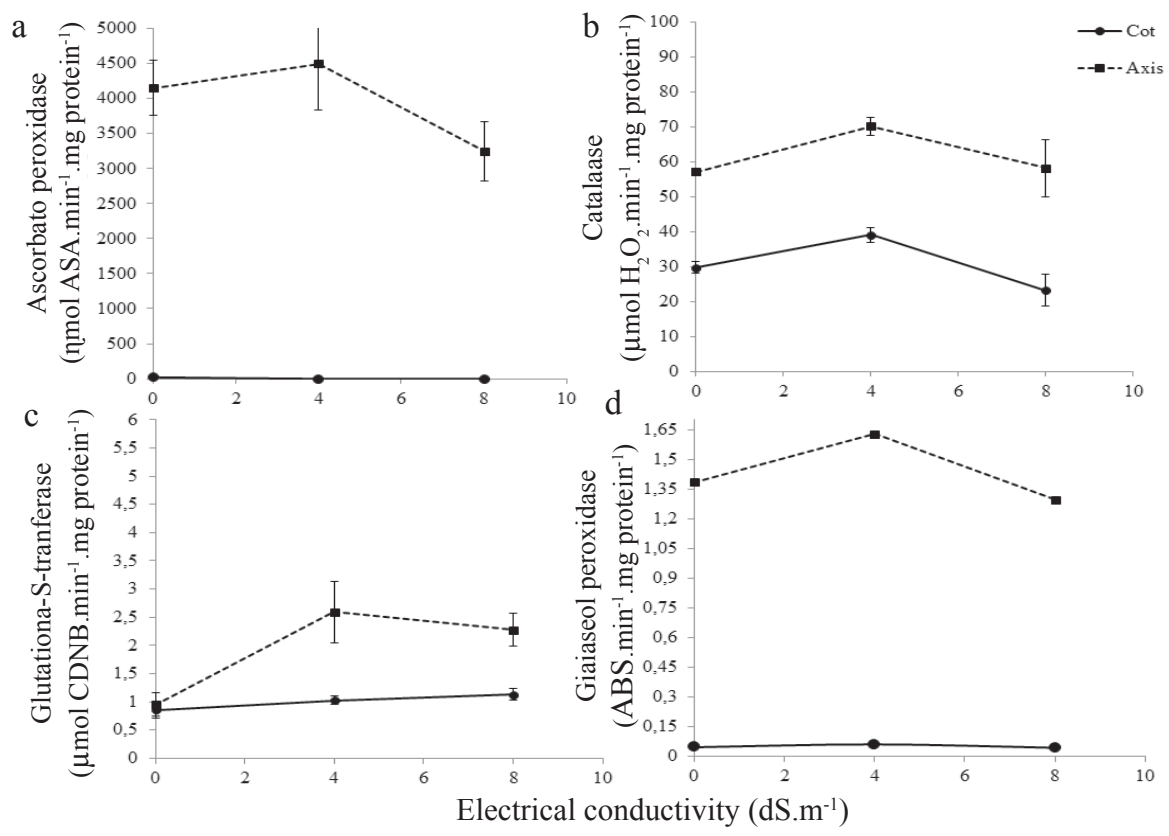

Figure 9. Ascorbate peroxidase (a), catalase (b), glutathione S-transferase (c) and guaiacol peroxidase (d) activities in 7 days germinated E. velutina embryonic axis (axis) and cotyledons (Cot) in different electrical conductivities. Vertical bars indicate standard errors.

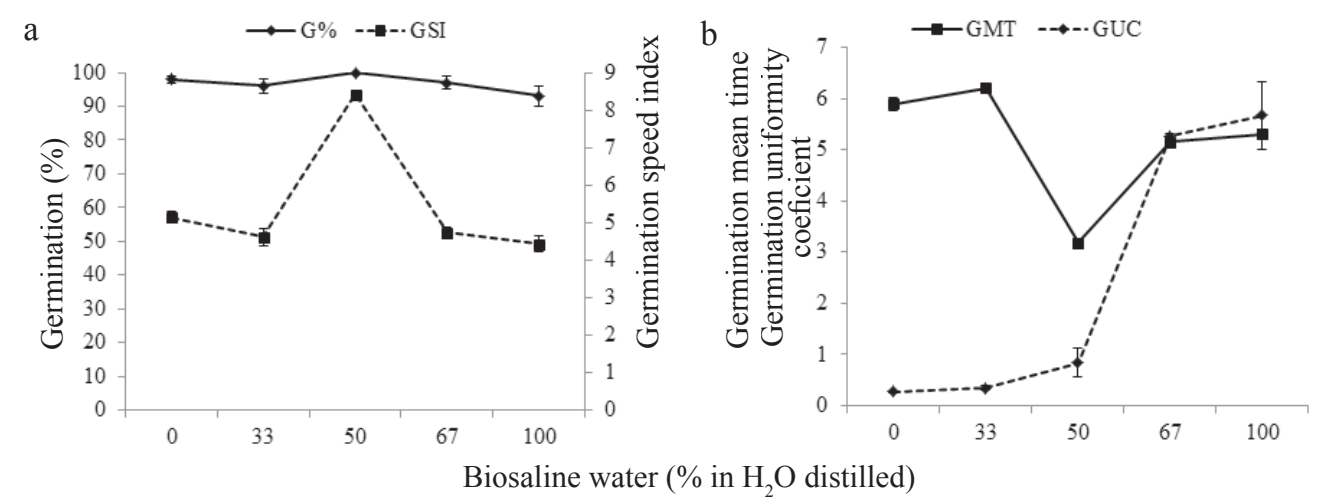

Figure 10. Germination percentage-G\%, germination speed index-GSI (a), germination mean time-GMT and germination uniformity coefficient- GUC (b) of E. velutina seeds in biosaline water. Vertical bars indicate standard errors of means.

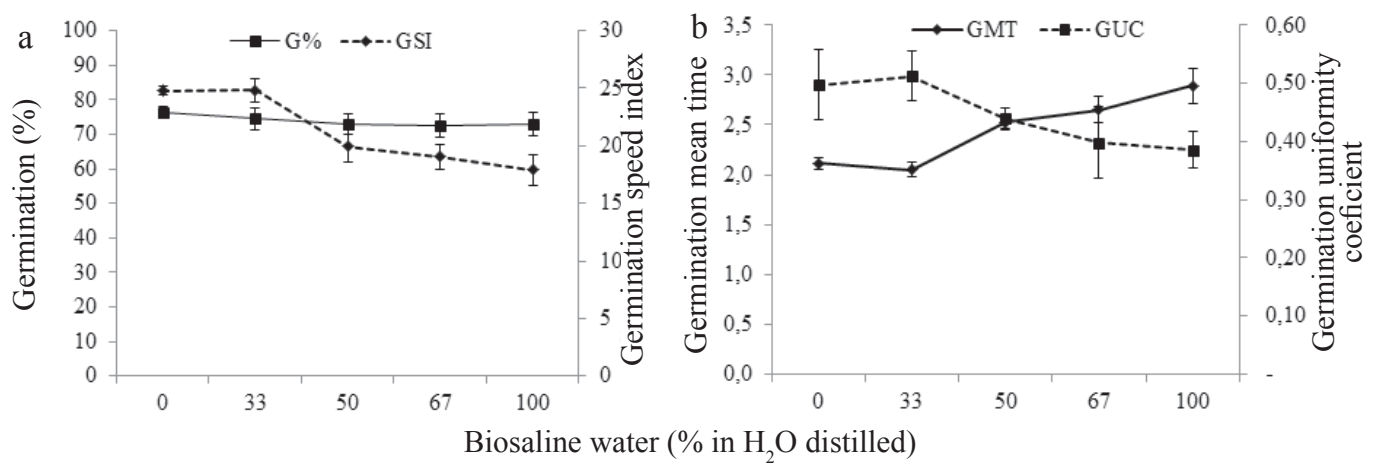

Figure 11. Germination percentage-G\%, germination speed index-GSI (a), germination mean time-GMT and germination uniformity coefficient- GUC (b) of M. urundeuva seeds in biosaline water. Vertical bars indicate standard errors of means. 

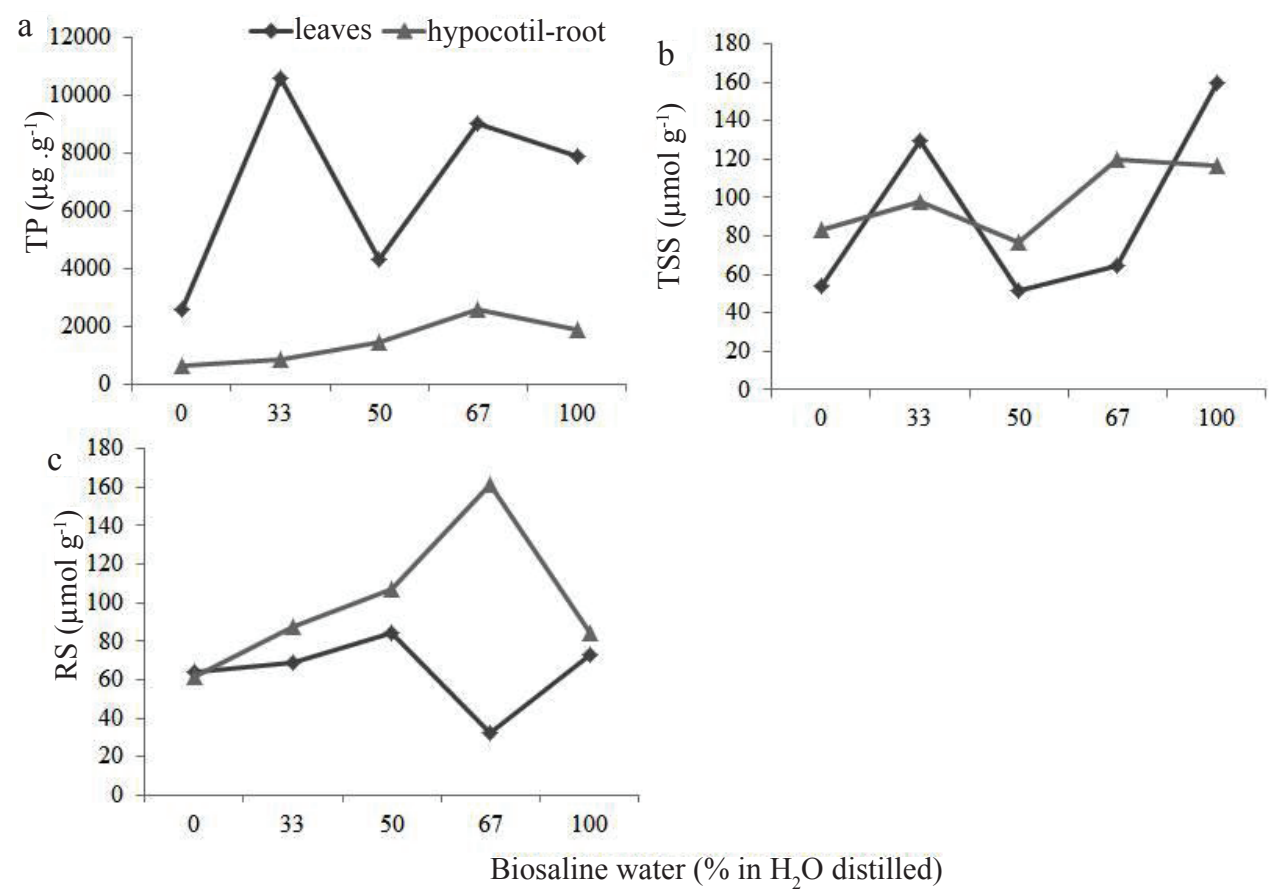

Figure 12. Total soluble proteins (TP), reducing sugars (RS), total soluble sugars (TSS) content in 7 days germinating $M$. urundeuva seeds in biosaline water. Vertical bars indicate standard errors of means.

The water content of seeds is one factor that determines the rate of water absorption during the germination process. The germination of the seed, i.e., its exit from a state of quiescence, begins with hydration and water absorption and follows a sequence of three primary steps: imbibition, biochemical and reparative processes and root protrusion (Bewley et al., 2013).

In seeds, excess salt causes the restriction of water uptake because of a decrease in the osmotic potential of the substrate, which delays imbibition or root elongation (Chaves et al., 2009). Salt also induces toxicity in the tissues because of the excessive accumulation of $\mathrm{Na}^{+}$and $\mathrm{Cl}^{-}$(Esteves and Suzuki, 2008; Góis et al., 2008). The sensitivity of seeds to stress during imbibition depends, among other factors, on temperature, the speed of water absorption and the seed moisture content. The interaction among these factors has a significant effect on the vigor of the plants that develop from such seeds (Bewley et al., 2013). In the present study, the germination of the Caatinga native forest seeds was mildly inhibited by the high-EC solutions. The germination of the seeds of A. macrocarpa (Figure 1), A. pyrifolium (Figure 4) and $M$. urundeuva (Oliveira et al., 2014) decreased only at EC levels above $12 \mathrm{dS} . \mathrm{m}^{1}$. The $E$. velutina seeds suffered no influence up to an EC level of $18 \mathrm{dS} . \mathrm{m}^{-1}$ (Figure 7). According to Braga et al. (2009), the germination and initial development period is a critical phase for the survival of forest species, especially at sites with limited water availability. The resistance to salt is described as the ability to prevent an excessive amount of salt in the substrate from reaching the plasma and to tolerate the toxic and osmotic effects associated with increased salt concentrations (Bewley et al., 2013). Increasing the cellular concentration of osmotically active compounds, such as proline, sugars and polyols, maintains the stability of certain macromolecules and thereby reduces the loss of enzymatic activity or membrane integrity that occurs with saline or water stress (Esteves and Suzuki, 2008).

Unlike the Caatinga seeds studied in this work, the seeds of Chorisia speciosa (A.St.-Hil.) did not show a high threshold of tolerance to salt stress and can be considered a glycophyte with moderate tolerance to $\mathrm{NaCl}$ (Fanti and Perez, 2004). A reduction in the percentage of germination attributable to increased water salinity was also observed in various legumes (Deminicis et al., 2007; Nunes et al., 2009).Tolerances to osmotic and ionic stress induced by water restriction and salt excess, respectively, are complex and often interrelated, involving the interaction of multiple factors (Verslues et al., 2006).

The accumulation of soluble sugars commonly occurs in the cells of plants subjected to salt stress. Sugars play a role in osmotic adjustment and have indirect protective effects, as in the stabilization of proteins (Bianchi et al., 1991). However, ionic toxicity can delay the emergence and mobilization of reserves or even decrease seed viability because of 
its influence on physiological and metabolic processes in embryonic tissues (Esteves and Suzuki, 2008). This influence is caused by a modification in the expression and the activity of regulatory enzymes in metabolic pathways (Wang et al., 2003). In the Caatinga seedlings, the brackish water influenced the mobilization of reserves (Figures 2, 6, 8 and 12). A. macrocarpa and $E$. velutina showed opposite responses to the increases in the $\mathrm{EC}$ of the $\mathrm{NaCl}$ solutions. The TSPs and RSs increased with the EC increases in the A. macrocarpa seedlings (Figure 2), but decreased in the E. velutina seedlings (Figure 8). However, the A. pyrifolium and M. urundeuva seedlings that developed in the increasing concentrations of biosaline water, showed no patterns in reserve mobilization (Figures 6,12). This might have resulted from organic matter and different salts present in the brackish groundwater because of the fish previously grown in the water (Table 1).

Plants often accumulate amino acids, amides, proteins, polyamines and other nitrogenous compounds under salt stress, and the content varies among species (Voigt et al., 2009). These compounds act in osmotic adjustment, the protection of cellular macromolecules, nutrient storage, the maintenance of cellular $\mathrm{pH}$, cell detoxification and the minimization of the effects of reactive oxygen species (ROS) in a species-specific manner (Ashraf and Harris, 2004), as shown by A. macrocarpa, A. pyrifolium and E. velutina (Figures 2, 6 and 8, respectively).

In general, seeds are well provided with antioxidant molecules and ROS scavengers. The ROS scavenger enzymes may reduce the toxic products resulting from free-radical attack before damage occurs (Nkang et al., 2000). Evidence for such an effect is provided by the activity of the antioxidant enzymes in the seeds of E. velutina (Figure 9).

Problems caused by water shortage have heightened interest in research on techniques for the safe and controlled application of wastewater in agriculture. Thus, many studies have been conducted to demonstrate the safety and efficacy of water reuse, particularly in countries or regions in which water resources are extremely limited. Wastewater may be important not only because of its use as an alternative water source but also because of its use in water conservation, the preservation of the environment and nutrient uptake and recycling (Medeiros et al., 2005). The specific characteristics of forestry activities make them a promising application for the future reuse of this wastewater supply, especially because these activities do not involve the production of food for human consumption and do not result in health hazards (Qadir et al., 2003). In this context, the native species of the semiarid region that are adapted to the severe water restrictions prevailing in the region are an important alternative to crop species, many of which are economically infeasible, for the use and the recovery of salinized areas (Silva et al., 2009). Furthermore, the use of wastewater from the aquaculture of fish adapted to brackish water, such as Nile tilapia, can be a viable approach for the production of native species for the reforestation of the Caatinga to preserve these species and this biome.

\section{Conclusions}

The seeds of species native to the Caatinga, including $A$. macrocarpa, M. urundeuva, A. pyrifolium and E. velutina, display a high salt tolerance and effective mechanisms for germinating in brackish water.

Biosaline agriculture may be a viable and sustainable alternative for the production of seedlings of these native species.

\section{References}

AGRA, M.F.; BARACHO, G.S.; BASÍLIO, I.J.; NURIT, K.; BARBOSA, D.A. Sinopse da flora medicinal do cariri paraibano. Oecologia Brasiliensis. v.11, n.3, p.323-330,2007.<http://www.ppgecologia.biologia.ufrj.br/ oecologia/index.php/oecologiabrasiliensis/article/view/147/113>

ARAÚJO-NETO, J.C.; AGUIAR, I.B.; FERREIRA, V.M. Efeito da temperatura e da luz na germinação de sementes de Acacia polyphylla DC. Revista Brasileira de Botânica, v.26, n.2, p.249-256, 2003.<http://www. scielo.br/pdf/rbb/v26n2/a13v26n2.pdf $>$

ASHRAF, M.; HARRIS, P.J.C. Potential biochemical indicators of salinity tolerance in plants. Plant Science, v.166, n.1, p.3-16, 2004. <http://dx.doi. org/10.1016/j.plantsci.2003.10.024>

BATES, L.S. Rapid determination of free proline for water stress studies. Plant Soil, v.39, p.205-207, 1973.<http://link.springer.com/ article/10.1007\%2FBF00018060\#page-1>

BEWLEY, J.D.; BRADFORD, K.J; HILHORST, K.H.W.M; NONOGAKI, H. Seeds: physiology of development germination and dormancy. New York: Springer, 2013, 392p.

BIANCHI, G.; GAMBA, A.; MURELLI, C.; SALAMINI, F.; BARTELS, D. Novel carbohydrate metabolism in the resurrection plant Craterostigma plantagineum. The Plant Journal, v.1, p.355-359, 1991. <http://onlinelibrary. wiley.com/doi/10.1046/j.1365-313X.1991.t01-11-00999.x/pdf>

BRAGA, L.F.; SOUZA, M.P.; ALMEIDA, T.A. Germinação de sementes de Enterolobium schomburgkii (Benth.) submetidas a estresse salino e aplicação de poliamina. Revista Brasileira de Plantas Medicinais, v.11, n.1, p.63-70, 2009. <http://dx.doi.org/10.1590/S1516-05722009000100011>

BRASIL. Ministério da Agricultura, Pecuária e Abastecimento. Regras para análise de sementes. Ministério da Agricultura, Pecuária e Abastecimento. Secretaria de Defesa Agropecuária. Brasília: Mapa/ACS, 2009. 395p. <http:// www.agricultura.gov.br/arq_editor/file/2946_regras_analise_sementes.pdf>

BRASIL. Ministério do Meio Ambiente. Lista de espécies ameaçadas de extinção. Instrução Normativa n.06, de 23 de setembro de 2008. Brasília, MMA. 2008<http://www.ibama.gov.br/index.php?option=com phocadow nload $\&$ view $=$ category $\&$ download $=1266: 05-2004-$ p $\&$ id $=40 \&$ Itemid $=331>$ 
CABRAL, E.L.; BARBOSA, D.C.A.; SIMABUKURO, E.A. Armazenamento e germinação de sementes de Tabebuia áurea (manso) Benth. \& Hook. f. ex. s. Moore. Acta Botanica Brasilica, v.17, n.4, p.609-617. 2003.<http://dx.doi. org/10.1590/S0102-33062003000400013>

CARVALHO, N. M.; NAKAGAWA, J. Sementes: ciência, tecnologia e produção. 4.ed. Jaboticabal: FUNEP, 2012. 590p.

CHAVES, M.M.; FLEXAS, J.; PINHEIRO, C. Photosynthesis under drought and salt stress: regulation mechanisms from whole plant to cell. Annals of Botany, v.103, n.4, p.551-560, 2009.<http://dx.doi.org/10.1093/aob/mcn125>

DANTAS, I.C.; SOUZA, C.M.C. Arborização urbana na cidade de Campina Grande-PB: inventário e suas espécies. Revista de Biologia e Ciências da Terra, v.4, n.2, p.1-18. 2004.<http://www.realbiologica.com.br/bioterra/ workspace/uploads/artigos/arborizaurbana-515646a391755.pdf>

DEMINICIS, B.B.; ALMEIDA, J.C.C.; ARAÚJO, S.A.C.; BLUME, M.C.; VIEIRA, H.D.; DOBBSS, L.B. Sementes de leguminosas submetidas a diferentes períodos de estresse salino. Archivo de Zootecnia, v.56, n.215, p.347-350, 2007.<http://www.uco.es/organiza/ servicios/publica/az/php/ az.php?idioma_global $=0 \&$ revista $=134 \&$ codigo $=1444>$

ESTEVES, B.S.; SUZUKI, M.S. Efeito da salinidade sobre as plantas. Oecologia Australis, v.12, n.4, p.662-679, 2008.<http://www. oecologiaaustralis.org/ojs/index.php/oa/ article/view/134/0>

FANTI, S.C.; PEREZ, S.C.J.G.A. Processo germinativo de sementes de painera sob estresses hídrico e salino. Pesquisa Agropecuária Brasileira, Brasília, v.39, n.9, p. 903-909, 2004. <http://dx.doi.org/10.1590/S0100204X2004000900010>

GÓIS, V.A.; TORRES, S.B.; PEREIRA, R.A. Germinação de sementes de maxixe submetidas a estresse salino. Revista Caatinga, v.21, n.4, p.64-67, 2008. $<$ http://periodicos.ufersa.edu.br/revistas/index.php/sistema/article/view/798>

HIRATA, R.; ZOBBI, J.; FERNANDES, A.; BERTOLO, R. Hidrogeología del Brasil: una breve crónica de las potencialidades, problemática y perspectivas. Boletin Geologico y Minero v.117, n.1, p.25-36. 2006.<http:// www.igme.es/internet/boletin/2006/117_1_2006/Art.2.PDF>

MASTERS, D. G.; BENES, S. E.; NORMAN, H.C. Biosaline agriculture for forage and livestock production. Agriculture, Ecosystems \& Environment, v.119, n.3-4, p.234-248, 2007.<http://dx.doi.org/10.1016/j. agee.2006.08.003>

MEDEIROS, S. S.; SOARES, A. A.; FERREIRA, P. A.; NEVES, J. C. L.; MATOS, A. T.; SOUZA, J. A. A. Utilização de água residuária de origem doméstica na agricultura: estudo das alterações químicas do solo. Revista Brasileira de Engenharia Agrícola e Ambiental, v.9, n.4, p.603-612, 2005. $<\mathrm{http}: / /$ dx.doi.org/10.1590/S1415-43662005000400026>

NKANG, A.; OMOKARO, D.; EGBE, A. Effects of desiccation on the lipid peroxidation and activities of peroxidase and polyphenoloxidase in seeds of Telfairia occidentalis. Seed Science and Technology, v.28, n.1, p.1-9, 2000. $<$ http://cat.inist.fr/?aModele=afficheN\&cpsidt=1455541 >

NUNES, A.S.; LOURENÇÃO, A.L.F.; PEZARICO, C.R.; SCALON, S.P.Q.; GONÇALVES, M.C. Fontes e níveis de salinidade na germinação de sementes de Crotalaria juncea L. Ciência Agrotecnologia, v.33, n.3, p.753757, 2009. <http://dx.doi.org/10.1590/S1413-70542009000300013>

OLIVEIRA, G.M.; MATIAS, J.R.; SILVA, P.P.; RIBEIRO, R.C.; DANTAS, B.F. Germinação de sementes de aroeira-do-sertão (Myracrodruon urundeuva Fr. All.) e mororó (Bauhinia cheilantha (Bong) Stend.) em diferentes condutividades elétricas.Revista Sodebras, v.9, n.105, 2014.
QADIR, M.; BOERS, T. M.; SCHUBERT, S.; GHAFOOR, A.; MURTAZA, G. Agricultural water management in water-starved countries: challenges and opportunities. Agricultural Water Management, v.62, n.3, p.165-185, 2003. $<$ http://dx.doi.org/10.1016/S0378-3774(03)00146-X>

RANAL, M.A.; SANTANA, D.G.D. How and why to measure the germination process? Revista Brasileira de Botânica, v.29, n.1, p.1-11. 2006.<http://dx.doi.org/10.1590/S0100-84042006000100002>

RIBEIRO, R.C.; DANTAS, B.F.; PELACANI, C.R. Mobilization of reserves and germination of seeds of Erythrina velutina Willd. (Leguminosae Papilionoideae) under different osmotic potentials. Revista Brasileira de Sementes, v.34, n.4, p.580-588, 2012.<http://dx.doi.org/10.1590/S0101$31222012000400008>$

RIBEIRO-FILHO, A.A.; FUNCH, L.S.; RODAL, M.J.N. Composição florística da floresta ciliar do Rio Mandassaia, Parque Nacional da Chapada Diamantina. Rodriguésia, v.60, n.2, p.265-276, 2009. <http://rodriguesia.jbrj. gov.br/FASCICULOS/ rodrig60_2/ 03-054-07.pdf>

RICHARDS, L.A. Suelos Salinos y Sodicos. Instituto Nacional de Investigaciones Agrícolas. México.1980. 171p.

RODAL, M.J.N.; MARTINS, F.R.; SAMPAIO, E.V.D.S.B. Levantamento quantitativo das plantas lenhosas em trechos de vegetação de caatinga em Pernambuco. Revista Caatinga, v.21, n.3, p.192-205, 2008.<http://periodicos. ufersa.edu.br/revistas/index.php/sistema/article/view/366/372>

SILVA, F.A.S.E.; AZEVEDO, C.A.V. A Versão do programa computacional Assistat para o sistema operacional Windows. Revista Brasileira de Produtos Agroindustriais, v.4, n.1, p. 71-78, 2002. < http://www.deag.ufcg.edu.br/rbpa/ rev41/Art410.pdf $>$

SILVA, M.B.R.; VIÉGAS, R.A.; DANTAS-NETO, J.; FARIAS, S.A.R. Estresse salino em plantas da espécie florestal sabiá. Caminhos da Geografia, v.10, n. 30, p.120-127, 2009. <http://www.seer.ufu.br/index.php/ caminhosdegeografia/article/view/16009/9024>

VERSLUES, P.E.; ARGAWAL, M.; KATIYAR-ARGAWAL, S.; ZHU, J.; ZHU, J.K. Methods and concepts in quantifying resistance to drought, salt and freezing abiotic stresses that affect plant water status. The Plant Journal, v.45, n.4, p.523-539, 2006. <http://dx.doi.org/ 10.1111/j.1365-313X.2005.02593.x>

VOIGT, E.L.; ALMEIDA, T.D.; CHAGAS, R.M.; PONTE, L.F.A.; VIÉGAS, R.A.; SILVEIRA, J.A.G. Source-sink regulation of cotyledonary reserve mobilization during cashew (Anacardium occidentale) seedling establishment under $\mathrm{NaCl}$ salinity. Journal of Plant Physiology, v.166, n.1, p.80-89, 2009. $<$ http://dx.doi.org/10.1016/j.jplph.2008.02.008>

WANG, W.; VINOCUR, B.; ALTMAN, A. Plant responses to drought, salinity and extreme temperatures: towards genetic engineering for stress tolerance. Planta, v.218, n.1, p. 1-14, 2003. <http://dx.doi.org/ 10.1007/ s00425-003-1105-5>

WEITBRECHT, K.; MÜLLER, K.; LEUBNER-METZGER, G. First off the mark: Early seed germination. Journal of Experimental Botany, v.62, n.10, p.3289-3309, 2011. <http://www.seedbiology.de/pdf2/WeitbrechtJXBreview2011.pdf> 